\title{
Szent György és Szent Demeter kultuszának hatása a magyar személynévadásra"
}

1. A vizsgálat célja, forrásai és módszerei. A névtudománynak köztudottan nagyszámú inter-, sőt inkább multidiszciplináris kapcsolódású területe létezik (bővebben 1. HAJDÚ 2003: 38-45; HOFFMANN 2015). A következőkben azt igyekszem egy esettanulmányon keresztül megvilágítani, hogy az utóbbi évtizedek személynévtörténeti kutatásai miképpen kapcsolódhatnak egy jellegzetesen multidiszciplináris területhez, a kultusztörténeti kutatásokhoz.

Az esettanulmányban Szent György és Szent Demeter magyarországi kultuszának a hazai személynévadásra gyakorolt hatását, annak időbeli, térbeli és társadalmi vonatkozásait tekintem át, a középkortól napjainkig. Az együttes tárgyalásnak módszertani okai vannak. A személynévállományban bekövetkező változások mértékének megfelelő értelmezéséhez ugyanis fontos, hogy egy-egy kultusz személynévadásra gyakorolt hatását ne önmagában, illetve ne csak az összképhez, hanem egy vagy több más kultusz hatásához is viszonyítva vizsgáljuk. Természetesen az sem mindegy, hogy mely kultuszok hatásait vetjük össze: e döntésben elsősorban kultusztörténeti szempontokat kell figyelembe vennünk (ezeket a konkrét esetet tekintve 1. a 2. pontban).

A vizsgálat középpontjában az egyénnevek állnak, hiszen ezek tükrözik legérzékenyebben a személynévadási szokások időbeli változását, valamint területi és társadalmi változatosságát, ennélfogva pedig a kultuszoknak és azok változásainak a hatását is. ${ }^{1}$ A vizsgálatban az utóbbi évtizedekben elkészült névszótárakra, személynévtörténeti adatbázisokra és névgyakorisági listákra támaszkodom (a vizsgált korszakok időrendi sorrendjében: ÁSznt.; SLíz 2011, 2017a; N. FODOR 2010; HAJDÚ 2003: 365-637; TMCsA.; valamint napjaink népesség-nyilvántartási statisztikái: Népnyilv.). Ezek elkészülte először teszi lehetővé a hasonló jellegü, makroszintü vizsgálatokat, bár egyelöre még némileg töredékes képet nyújtva.

A szentek tisztelete számos módon motiválhatja az egyénnévadást; amellett, hogy a névadó valamiért különösen tiszteli az adott szentet, szóba jöhet például a szent napján vagy annak közelében történő születés és még számos más ok is. Ráadásul egy szent nevének adása mögött a kultuszától független indíték is állhat (pl. névörökítés, esztétikai és érzelmi szempontok). Egy történeti makrovizsgálat esetében ezek természetesen felderíthetetlenek, ezért sosem lehetünk biztosak abban, hogy az adatok által tükrözött névállománybeli változás, illetve változatosság

${ }^{*}$ Készült az ELTE Bölcsészettudományi Karán a Tématerületi Kiválósági Programnak, a Magyar Tudományos Akadémia Bolyai János Kutatási Ösztöndíjának, valamint az Innovációs és Technológiai Minisztérium ÚNKP-19-4 kódszámú Új Nemzeti Kiválóság Programjának a támogatásával.

${ }^{1}$ Mivel a tanulmány kereteit szétfeszítené, itt csak utalok rá, hogy jóval kisebb mértékben és szűkebb felhasználhatósággal, de a családnevek vizsgálata is hozhat eredményeket a hasonló célú vizsgálatokban. (Erre példaként a Szent László-kultusz kapcsán 1. SLíz megj. e.)

Magyar Nyelv 116. 2020: 286-298. DOI: 10.18349/MagyarNyelv.2020.3.286 
valóban a kultusz hatására következett be. Az egyes korszakok személynévtörténeti jellemzőinek, valamint a kultusztörténeti jellemzőknek és változásoknak az adott nevek történetében bekövetkező változásokkal való összevetése azonban lehetőséget nyújt a kultusz és a névadás közti összefüggések több-kevesebb biztonsággal való feltárására, mint azt a későbbiekben látni fogjuk. (A kultusztörténeti fogódzók kapcsán bővebben 1. SLíz 2017b, 2020.)

\section{Szent György és Szent Demeter kultusza a középkori Magyarorszá-} gon. A két szent kultuszának és névadásra gyakorolt hatásának együttes tárgyalását több szempont is motiválja: mindketten harcos szentek, és kultuszuk erősen - de közel sem kizárólagosan - kötődik a keleti kereszténységhez.

Mindkét kultusz igen korán ismertté vált Magyarországon. Szent György hazai tiszteletének elterjesztésében bizonyára komoly szerepe volt Gellért püspöknek. György győzelemadó szent volta mellett bizonyára ezzel is összefügg, hogy a Gellért-legenda szerint az Ajtonyt Szent György segítségével legyőző Csanád alapította oroszlánosi monostort, valamint az István által Marosváron szervezett új püspökség egyházát is neki szentelték. De nemcsak Gellért, hanem Gizella családja is nagy tisztelője volt Szent Györgynek. Mindezek alapján nem meglepő, hogy István az 1018-as, bolgárok elleni hadjáratáról hadizsákmányként magával hozta Szent György fejereklyéjét, és a szent veszprémi egyházában helyezte el, 1030-ban pedig támogatta a szent keleti kultuszközpontjában, Lyddában a romos templom, kolostor és zarándokszállás újjáépítését. (MAGYAR 2006: 30-31.)

Szent Demeter kultusza szintén korán jelen lehetett az országban. Hazai fellendülését és a hazai legenda 12-13. század fordulójára tehető megszületését TÓTH PÉTER szerint az eredményezhette, hogy 1180-ban III. Béla végleg megszerezte a korábban részben már magyar fennhatóság alatt lévő, majd a bizánciak által elfoglalt Sirmiumot (azaz Szávaszentdemetert). A település a szent szülőhelyeként Szaloniki mellett a kultusz másik központjának számított, feltehetőleg már a népvándorlás elött állhatott itt temploma Szent Demeternek. (TóTH P. 2007a: 95-96.) A kultusz ugyanakkor Magyarországon sosem vált olyan jelentőségüvé, mint Szent Györgyé, mint az a két szent fennmaradt ábrázolásainak számából és elterjedtségéből is kitünik.

Szent Demeter első hazai emlékei külföldön készültek (pl. a Szent Korona alsó részén Szent György párjaként látható). Bizonyára ábrázolták a nyugati kereszténység templomainak freskóin is a katonaszentek között, mivel azonban nem rendelkezik saját attribútummal, alakja nem azonosítható teljes biztonsággal. Néhány ortodox templomban azonban találni egyértelműen őt ábrázoló, 14-15. századi képet. (TERDIK 2007: 176-181.) Ezzel szemben Szent György-ábrázolás jóval nagyobb számban maradt fenn a középkorból (szárnyasoltárok, freskók, szobrok, kályhacsempék, pecsétek; összefoglalóan 1. pl. BÁLINT 1977. 1: 306-307, 2: 461462; MAGYAR 2006: 34-38).

A patrocíniumok és a belőlük keletkezett településnevek száma szintén azt látszik alátámasztani, hogy Szent György tisztelete erőteljesebb volt a középkori Magyarországon Szent Demeterénél: György az 5. helyet foglalja el a patrocíniummal rendelkező szentek gyakorisági sorrendjében, míg Demeter az első 
15-be sem került be (vö. HofFMANN 2016: 83). A patrocíniumi helynevek esetében hasonlót tapasztalhatunk: Szent György a 2. (vagyis számos európai országhoz hasonlóan a leggyakoribbak közt van; vö. TóTH V. 2012: 294), Szent Demeter viszont csak a 19. helyet foglalja el (MEZÖ 1996: 225).

A lovagi kultúra 14. századi, utolsó magyarországi virágzása a katonaszentek kultuszára pozitív hatással volt. Ez - Szent László tisztelete mellett - a legfeltünőbben Szent György esetében mutatkozott meg, akinek kultuszában egyértelmủen a 14-15. század jelenti a virágkort Magyarországon. György annak ellenére lett Európa legünnepeltebb katonaszentje, hogy az egyház már igen korán kétségbe vonta történelmi hitelességét, a 692-es trullai zsinat pedig be is tiltotta ünneplését (MKL. György a.). Bár Rómában már az 5. században volt temploma, Keletről induló tisztelete csak a keresztes hadjáratok következtében terjedt el egész Európában; Szent György ennek köszönhetően vált az ideális lovag prototípusává. Nem meglepő hát, hogy Európa első világi lovagrendjét, a Károly Róbert által 1326-ban alapított Szent György-rendet is róla nevezték el. (BÁLINT 1977. 1: 298; GULYÁS 1997; MAGYAR 2006: 5-12.)

A kultuszok középkori történetének rövid áttekintése után lássuk, hogyan tükröződhettek e jellemzők a korabeli egyénnévállományban.

3. A György és a Demeter név gyakoriságának változása a középkorban. A György első ismert hazai említése - kultuszához hasonlóan - igen korai: már 1051-ből adatolható egyénnévként (ÁSznt. Georgius a.). A Demeter első hazai adata ezzel szemben csak 1138-ból maradt fenn (ÁSznt. Demeter stb. a.), ami persze nem zárja ki, hogy már a 11. században is használatos lehetett Magyarországon.

A leggyakrabban előforduló latin alapváltozat mellett mindkét névnek több magyar és egyéb nyelvü változata maradt fenn a forrásokban. A György magyar alapváltozata mellett (Giurg Gurgh Gyurg Gyurgh Gyurgy stb.) számos, elvonással és továbbképzéssel alakult változatot találunk mind az Arpád-, mind az Anjou-korban (ÁSznt., SLíz 2011, 2017a. Georgius a.): Györk Gyürk (Geurk Giurk Gurk Gyurk stb.), Gyure Gyüre (Gure Gyure Gywre stb.), Györke Gyürke (Gurge Gurke Gyurke stb.), emellett $J$-s kezdetü változatai is fellelhetök; pl. Iure, Jurk.

A Demeter magyar alapváltozata mellett kialakult egyéb változatok inkább az Árpád-korra jellemzőek, az Anjou-korra jócskán megcsappant a feljegyzett változatok variabilitása; pl. Deme, Demes, Demsa, Dene, Denk, Dense (ÁSznt., SLíz 2011, 2017a. Demetrius a.). Ráadásul e változatok nem mind tartoznak feltétlenül a Demeter-hez, több hasonló kezdetü névből is kialakulhattak (pl. a Damján név Demjén változatából vagy a Deniper-böl; vö. ÁSznt.).

Ami a nevek Árpád-kori gyakoriságát illeti, összefoglaló statisztika híján, FEHÉRTÓI KATALINnak az Árpád-kori kis személynévtára (1983) alapján készített, pontos adatokkal nem szolgáló összegzésére (FEHÉRTÓI 1997: 73) támaszkodva jelenleg mindössze annyit lehet megállapítani, hogy a György a 11. leggyakoribb egyházi név volt, a Demeter viszont nem szerepel az első 12 egyházi név között. Ez egybecseng a kultuszok, illetve a patrocíniumok és a patrocíniumi helynevek kapcsán látottakkal, melyek a Szent Demeter-kultusz kisebb jelentőségét mutatják. 
Saját 13-14. századi korpuszom (SLíz 2011, 2017a) birtokosok neveit tartalmazó része alapján úgy tünik, hogy a 13. század folyamán a György népszerüsége csökkent, a Demeter-é pedig stagnált (aránya ugyan nőtt, de ez inkább csak az egyházi nevek arányának általános növekedésével magyarázható, így előrébb lépni egyelőre nem tudott, sőt egy pozícióval lejjebb is csúszott). A 13-14. század fordulójától azonban mindkettő sorsában fordulat állt be (1. ábra). Ez arra enged következtetni, hogy gyakoribbá válásukat a lovagi kultúrában megnövekedett tiszteletük hatása eredményezhette.

\section{1. ábra}

A György és a Demeter gyakorisága (\%, balra) és pozíciója (sorszám, jobbra) a 13-14. századi korpuszban, a birtokosok névanyagában (SLíz 2011, 2017a alapján)

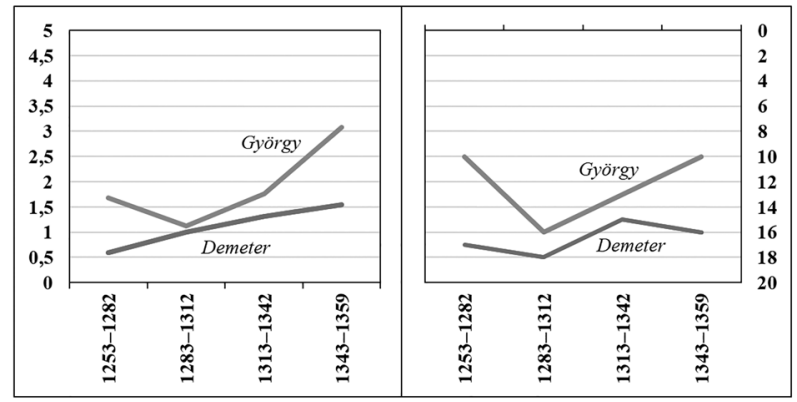

A György népszerüségét ugyanakkor a László-éval is érdemes összevetni (2. ábra.), KLANICZAY GÁBOR (2018) ugyanis az Európa-szerte legjelentősebb lovagszent és a magyar szent lovagkirály 14. századi kultuszának egymáshoz való viszonyát egyfajta rivalizálásként ábrázolja. E felfogás létjogosultságát a személynévi adatok is igazolják: bár a két név ugyanazon pozícióból indult a 13. század közepén, a György kevésbé tudott eredményes lenni a lovagi kultúra és a szent király kultuszát segítő uralkodói támogatás által legerősebben befolyásolt birtokos rétegben.

\section{2. ábra}

A György és a László gyakorisága (\%, balra) és pozíciója (sorszám, jobbra) a 13-14. századi korpuszban, a birtokosok névanyagában (SLíz 2011, 2017a alapján)

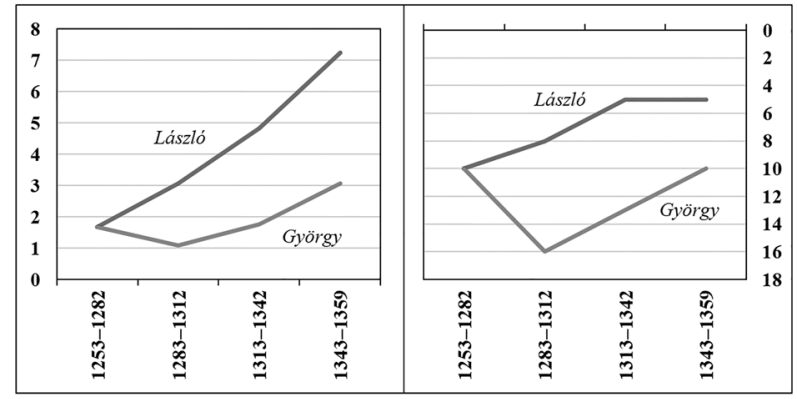


Folytatva a György és a Demeter név történetét, azt látjuk, hogy az 1389-es nyugat-magyarországi, alsólendvai Bánffy-féle jobbágyösszeírásban az előbbi a 3. leggyakoribb, az utóbbi pedig a 17. helyet foglalja el a gyakorisági sorrendben (FEHÉRTÓI 1968; adatait korrigálva N. FODOR 2010: 124). Ebböl arra következtethetünk, hogy a György népszerüsége tovább növekedett a 14. század második felében, s ezt erősíti meg az is, hogy az ország másik részéből, a Felső-Tisza-vidékről származó korpusz időben legközelebb eső szakaszában (1401-1425) szintén a 3. helyen áll (N. FODOR 2010: 126). A teljes, 1401-1526 közötti korpusz alapján (3. ábra) úgy tünik, hogy a György gyakorisága a kultusz 15. századi virágzása ellenére ekkoriban jelentős mértékben csökkent. A Demeter ezzel szemben egy ideig meglepően jelentős mértékben erösödött, de lendülete a 15 . század végére ki is fulladt.

\section{3. ábra}

A György és a Demeter gyakorisága (\%, balra) és pozíciója (sorszám, jobbra) az 1401-1526 közötti korpuszban (N. FODOR 2010: 126-130)

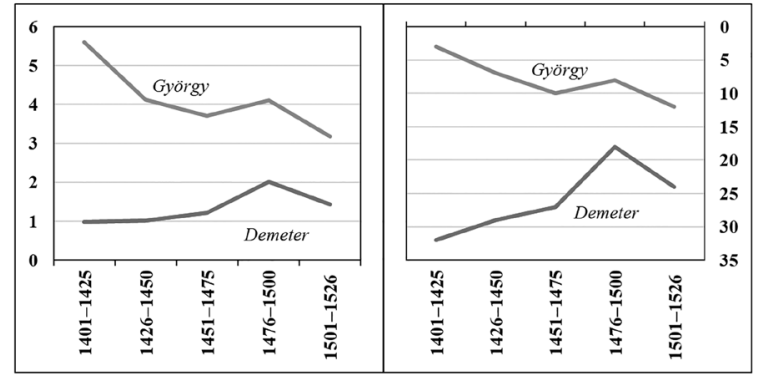

Ha azonban összevetjük ezt ugyanezen időszakból, de más területekről készült statisztikákkal, akkor egészen más képet kapunk. A Várdai-uradalom 1453-as öszszeírásában Kisvárda környékén például egyik név se került be a leggyakoribb 20 közé (vö. MEzÖ 1970), míg az 1469-es, Eszék környéki összeírásban a György a 3., a Demeter pedig a 16. helyen áll (HAJDÚ 2003: 363). Mivel a György egy Esztergom környéki, 15. századi korpuszban is csak a 13. helyen áll (HAJDÚ 2003: 363), valószínüsíthetô, hogy az ország nagyobb részén valóban csökkent a gyakorisága a 14. századihoz képest. Vagyis jellemzően a 14. század divatneve volt, amely a lovagi kultúra hatására népszerủvé vált, majd feltehetőleg - a divatnevek tipikus viselkedésének megfelelően - a viszonylag hirtelen megnőtt gyakoriság miatti visszahatásként a 15. században visszasüllyedt korábbi szintjére. A Demeter erősödése - habár vidékenként eltérő mértékben - szintén országos jelenség lehetett, hiszen a HAJDÚféle esztergomi korpuszban (2003: 363) is a 18. helyet foglalja el.

\section{Szent György és Szent Demeter kultusza és nevük gyakorisága a kora} újkori Magyarországon. HAJDÚ MIHÁLY kora újkori korpusza (2003: 371-393) alapján úgy tủnik, hogy a György gyakorisága nem sínylette meg a reformációt és a török hódítást, sőt még javítani is tudta pozícióját. A Demeter azonban, amely korábban is kevésbé volt népszerü, komoly válságba került: még a 25 leggyakoribb név közé sem jutott be, eltekintve egy rövid időszaktól a 17. század közepén (4. ábra). 


\section{4. ábra}

A György és a Demeter gyakorisága (\%, balra) és pozíciója (sorszám, jobbra)

1526-1772 között (HAJDÚ 2003: 371-393. alapján)

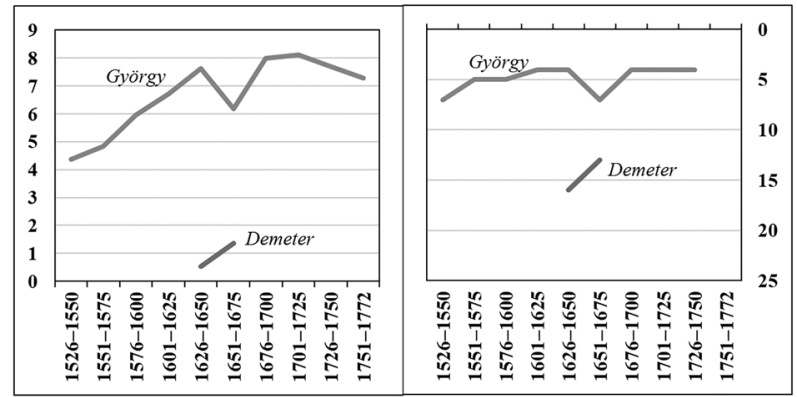

Vajon mi okozhatta ezt a különbséget? A válasz nyilvánvalóan összetett. Az ereklyék pusztulása például komoly csapást jelenthetett egy-egy kultusz számára. Ilyen lehetett az, hogy Szent György Veszprémben örzött fejereklyéje a török elöl menekítve szétporladt. A várost ráadásul 1592-ben elfoglalták a törökök, újabb csapást mérve ezzel a kultuszra egyik fontos központjának elveszítésével. (MAGYAR 2006: 41.) Hogy ez mégsem vezetett a kultusz és a névgyakoriság korabeli hanyatlásához, az számos tényező együtthatásának köszönhető. A kultusz szempontjából a legnagyobb jelentősége a szent szimbólumértékének volt: a sárkány legyőzése a hitetlenek (törökök, protestánsok) felett remélt győzelmet szimbolizálhatta. Ehhez hozzájárultak a sárkányöléshez kapcsolódó történetek, melyek nemcsak Magyarországon, hanem Európa számos országában elterjedtek (mondák, népénekek, balladák). Magyarországon a Báthoryak, illetve Szatmárban Bethlen Gábor köré is szövődtek ilyenek; az elöbbieknek a címerükben is megjelentek a sárkányfogak, illetve a sárkány. De a törökellenes harcokhoz kötődnek a katonák által talizmánként viselt Szent György-tallérok is, amelyeket a 17. században Körmöcbányán vertek külföldi mintára. (BÁliNT 1977. 1: 303; GULYÁs 196-201; MAGYAR 2006: 41-50.) Emellett Szent György a 14 segítőszent egyikévé is vált, így ez a 14. században német hatásra kialakult közös tisztelet is erősítette kultuszát. Ráadásul e csoportbeli egyik szerepe a vallási kételyek elleni védelem volt (MKL. tizennégy segítöszent a.), így alakja a protestánsok elleni küzdelemben is felhasználható volt. Ünnepnapja, április 23-a a tavasz kezdetét jelezte, számos népszokás és hagyomány kapcsolódott hozzá, illetve adófizetési és tisztújítási határnapként is szolgált (összefoglalóan 1. pl. BÁLINT 1977. 1: 307-314; MKL. György a.). Mindezek mellett a nevet a protestánsok számára is elfogadhatóvá tette, hogy olyan jeles református személyiségek is viselték, mint I. és II. Rákóczi György erdélyi fejedelmek.

A Demeter-nek a gyakori nevek közül való eltünése ezzel szemben egyértelmü okra vezethetö vissza: a 17. századra a kultusz szinte teljesen kiszorult a köztudatból. A török hódítás miatt ugyanis a hazai kiadású liturgikus könyvek kiadása szinte teljesen megszünt, ezért végül 1630-ban, a nagyszombati zsinaton Pázmány ösztönzésére a magyar püspökök úgy döntöttek, a régi rítus helyett elfogadják a római kánont. Ettől kezdve azt az Európa-szerte elterjedt legendaváltozatot használták, 
amely nem tudott a szent sirmiumi születéséről, így Szent Demeter magyar szentként való értékelése elhalványult. (TóTH P. 2007b: 129-132.) Ezt tükrözi, hogy a 17-18. század két legfontosabb szentéletrajz-gyüjteménye, a Hevenesi Gábor-féle Régi magyar szentség és Illyés András munkája, A szentek élete sem tartalmazta az életrajzát (TERDIK 2008: 188), s katolikus ábrázolása sem ismert a 16. század második fele és a 18. század közepe közti közel kétszáz évböl (TERDIK 2008: 197). Ráadásul míg a másik két szent napjához számos néphagyomány kapcsolódott, Szent Demeter tiszteletének csak kevés nyoma maradt e téren (BÁRTH 2007: 206-208.)

A nevek gyakoriságáról kirajzolódó képet kiegészíthetjük a földrajzi megoszlás vizsgálatával N. FODOR JÁNOS Történeti magyar családnévatlaszának (TMCsA.) egyénnévi modulja alapján. ${ }^{2}$ Az 1713-as erdélyi és az 1715-ös országos összeírás alapján elkészült járási szintü térképen (5. ábra) jól látható, hogy a gyakorisági listán a 2. helyet elfoglaló György egyénnév az ország minden járásában és minden etnikuma körében jelen volt, és még a jellemzőbben református alföldi részeken is többnyire meghaladta a 4\%-ot. Bár a latinosítás miatt számos esetben nem tudni, hogy az adott személy megnevezésére milyen nyelvü változat volt használatos a szóbeliségben, azért böségesen találunk élőnyelvi változatokat. A legmegterheltebbek, illetve a legtöbb írásváltozatban előfordulók magyarok (pl. 362 György, 194 Gjörgj, 187 György, 179 Györgj, 126 Györgj, 109 Geőrgj, 105 Gjörgj, 14 Geörgy), de böséggel akadnak szláv (jórészt szlovák) és kisebb számban német változatok is, habár kisebb megterheltségben (pl. szláv: 54 Jura, 36 Jurko, 23 Juro, 14 Jurco, 8 Jurik, 6 Jurek, 2 Gyuricza, 2 Juricza; német: 5 Jörgh, 4 Georg, 4 Jorgh, 1 Jörge). Feltehetőleg román változat a Gyorgie (2), Gjorgje (1), habár lehetnek a magyar Györgye mellékjel nélkül lejegyzett változatai is; biztosan román viszont a Gyorgu (1).

\section{5. ábra}

A György egyénnév különbözö nyelvü adatainak területi megoszlása 1713-1715-ben (TMCsA.)

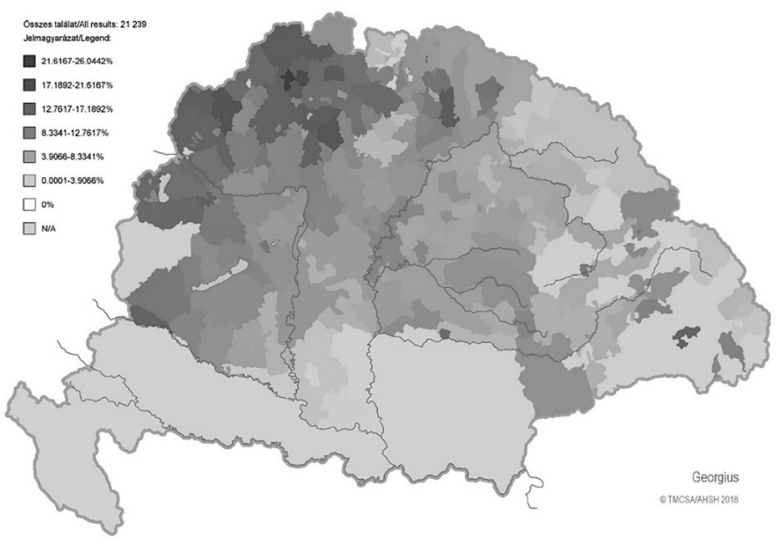

${ }^{2} \mathrm{Az}$ adatokért és térképre vetítésükért ezúton is köszönetemet fejezem ki N. FODOR JÁNOSnak. A térképeken egységesen szürkével színezett területekről az adott évekből jelenleg nem rendelkezünk összeírással. 


\section{6. ábra}

A Demeter egyénnév különböző nyelvű adatainak területi megoszlása 1713-1715-ben (TMCsA.)

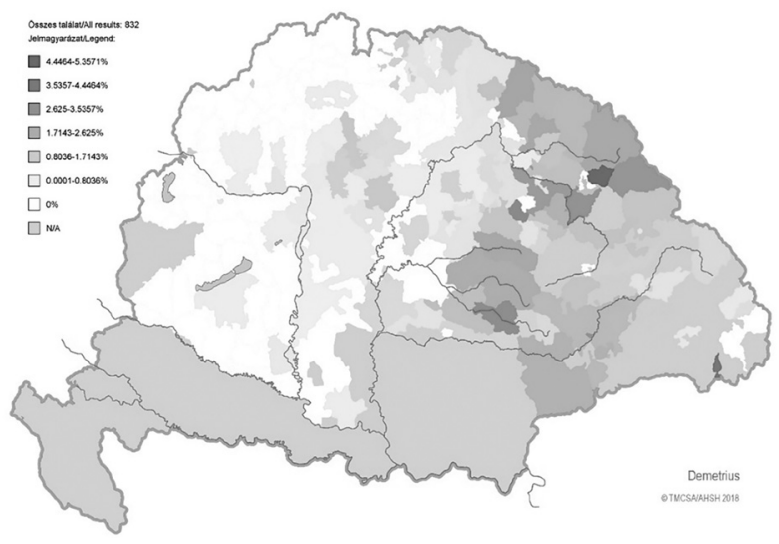

Ezzel szemben a Demeter egyénnév térképe - a fenti elemzések alapján várt eredményt mutatva - igen alacsony népszerüséget mutat (6. ábra). Míg a György legnagyobb megterheltsége $26 \%$, addig a Demeter-é mindössze $5,4 \%$, és a Dunántúl túlnyomó részén, valamint a Felvidék nyugati és középső részén, illetve több alföldi járásban és Bácsban egyáltalán nem jelenik meg. Bár Erdély jelentős részéből nincsen adat, az így is látszik, hogy a név ekkorra már szinte csak az ortodox és görögkatolikus, jórészt románok és ruszinok lakta vidékeken volt közepesen gyakorinak tekinthető. Ezt támasztja alá a román és szláv változatok jelentős száma, és némelyiküknek a többihez viszonyítva jelentős megterheltsége is (pl. 160 Dumitru, 23 Demitru, 11 Dumitr, 10 Dimitru, 6 Dumetru, 2 Dumitrul, 1-2 Demko, Dima, Dimko, Gyima); miközben az egyértelmúen magyaros Dömötör mindössze egyszer fordul elő a teljes 1713-1715-ös korpuszban. Érdekes, hogy míg a magyarországi szerbek körében a szent nagy tiszteletnek örvendett (vö. TERDIK 2007: 200), ez a névadásukban kevéssé tükröződik. Ha összevetjük ezt a képet a Demeter családnévével (7. ábra), egyértelmüen kirajzolódik a név pozícióvesztése. A térkép értelmezéséhez persze figyelembe kell vennünk, hogy természetesen nem minden Demeter neve maradt fenn családnévvé válva a 18 . század elejére, és a török korban, illetve azt követően komoly mértékü népességmozgással is számolhatunk. Még ezeket figyelembe véve is jól látszik azonban, hogy 2-3 évszázaddal korábban, a családnevek kialakulásának idején, amikor e nevek az apa egyénnevéből létrejöhettek, a Demeter sokkal nagyobb területen lehetett használatos, így a Dunántúlon és a Felvidék nyugati részein is. 
7. ábra

A Demeter családnév földrajzi megoszlása 1713-1715-ben (TMCsA.)

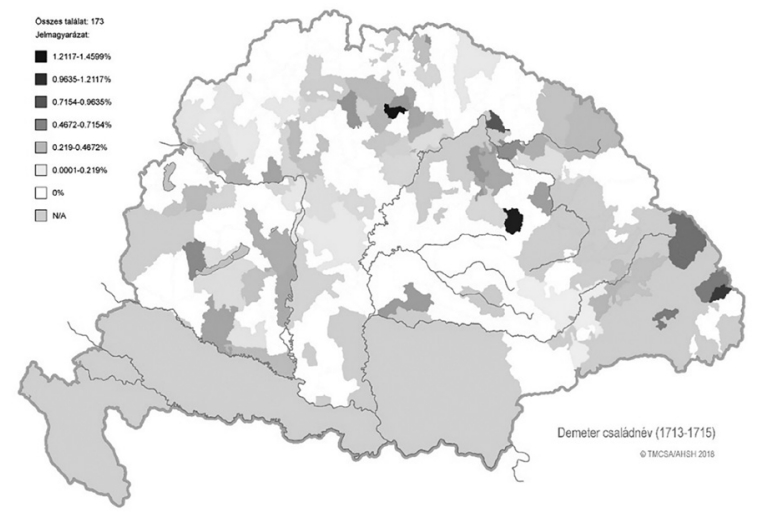

5. A György és a Demeter egyénnév gyakoriságának változása az újkorban. A két név újkori gyakoriságát egyaránt a fokozatos népszerütlenedés jellemzi, bár természetesen eltérő mértékben (8. ábra). A György a változás ellenére is a gyakoriak között maradt a 20. század közepére is, a Demeter viszont a ritka nevek közé süllyedt. A korábbi időszak eredményei alapján ezek nem okoznak különösebb meglepetést. Mivel a kultuszok újkori történetében újfajta, intenzív hatás nem tapintható ki, feltételezhető, hogy e tendenciák inkább a névadási szokások és a névállomány változásának következményei: a 18. században a betelepített német és szlovák lakosság, illetve az erősödő polgárság által ismertté tett nevekkel és újabban népszerübbé váló szentkultuszokkal (pl. Károly, Lajos, Ignác, Rókus), valamint az új nemzeti névkincs fokozatos megjelenésével (pl. Gyula, Kálmán, Béla, Jenö) nőtt a választható nevek száma, csökkent az átlagos megterheltség, és a régóta használatban lévő neveket hátrébb szorították az újabb, az előző évszázadok lassú változásaihoz képest gyorsan divatosabbá váló nevek. Ezt támasztja alá az is, hogy a György gyakoriságának rendkívül meredek zuhanása a 19. század utolsó harmadáig mindössze 6 helynyi hátrálást jelentett.

\section{8. ábra}

A György és a Demeter gyakorisága (\%, balra) és pozíciója (sorszám, jobbra)

1770-1967 között (HAJDÚ 2003: 554-576. alapján)

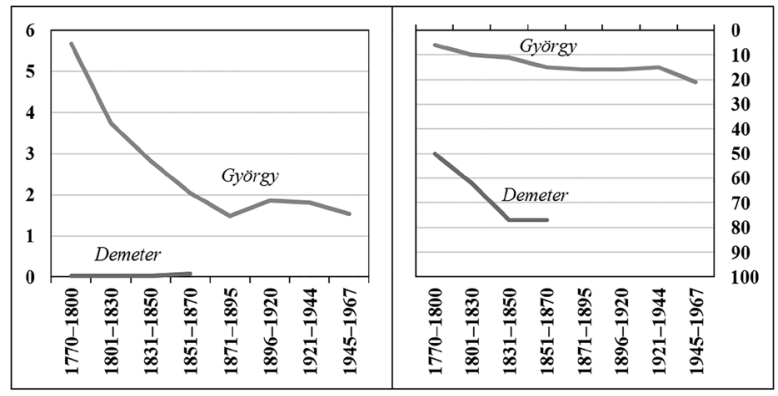


Napjainkban a György a 100 leggyakoribb férfinév között van az össznépességet tekintve, annak ellenére, hogy Szent Györgyöt - nem találván hiteles adatot létezésére - 1969-ben törölték a szentek sorából (MKL. György a.). Ez azonban nincs különösebb hatással a név gyakoriságára, hiszen a szentkultuszok $-\mathrm{s}$ tágabban értve: a vallási szempontok - már igencsak háttérbe szorultak a különböző lehetséges névadási motivációk sorában (továbbá a kereszténység mellett számos más vallás és egyház is jelen van a mai magyar társadalomban).

2019-ben a György a 19. helyen állt össznépességben, a Demeter és ajakkerekítéses változata, a Dömötör viszont nem jutott be az első 100 név közé (Népnyilv.). Az újszülöttek névállományát áttekintve azonban azt láthatjuk, hogy a György kedveltsége folyamatosan csökken még a legutóbbi évek folyamán is (9. ábra).

\section{9. ábra}

A György gyakorisága (\%, balra) és pozíciója (sorszám, jobbra) 2003-2019 között az újszülöttek körében leggyakoribb 100 névhez viszonyítva (a Népnyilv. alapján) $)^{3}$

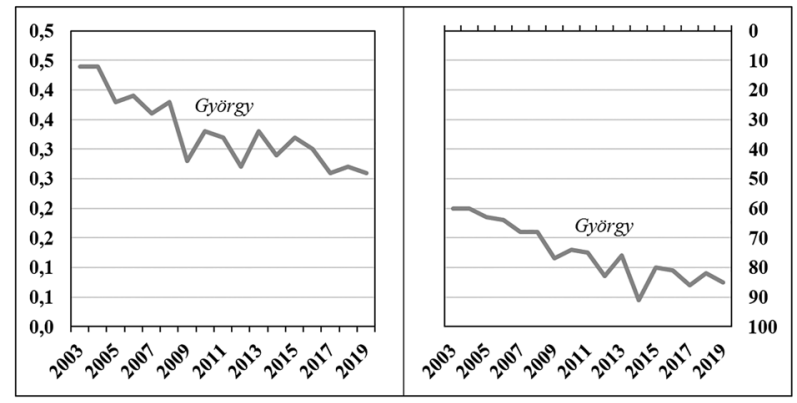

Ugyanakkor második névként szívesebben adták ugyanezen időszakban a szülők, számos más, napjainkban hagyományosként értékelt névhez (pl. István, Imre) hasonlóan. ${ }^{4}$ Míg ugyanis 2019-ben első névként a 85. helyen állt, és az elmúlt 15 évben 25 helyet hátrált, addig második névként a százas listán szereplő nevek közt a 30. pozíciót foglalta el, mindössze 4 helyet rontva ugyanezen időszak alatt.

${ }^{3}$ Mivel csak a 100 leggyakoribb név szerepel a listában, és az adott évben születettek összlétszáma sem derül ki belőle, az egyes nevek számát csupán az első 100 név együttes számához lehet viszonyítani, természetesen nemenként.

${ }^{4}$ A második névként adás vizsgálatának szintén van korlátja: mivel a statisztikák az első nevek alapján közlik a leggyakoribb 100-at, csak annyi derül ki belölük, hogy ezeket a neveket hányszor adták második névként. A grafikon tehát azt tudja csak bemutatni, hogy a György második névként milyen arányban van jelen azon nevek között, amelyek első névként bekerültek az első 100ba. A változást azonban ez is jól tükrözi. 


\section{0. ábra}

A György pozíciója (sorszám) első és második egyénnévként 2003-2019 között az első névként leggyakrabban adott 100 név között (a Népnyilv. alapján)

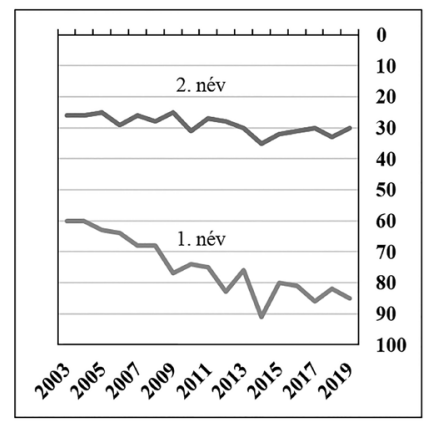

6. Kitekintés. Összegzésként megállapíthatjuk, hogy a Demeter népszerüségét erősebben befolyásolhatta a mögötte álló szent tisztelete. A György - bizonyára erőteljesebb kultuszának is köszönhetően - jóval szélesebb körben elterjedt, így az évszázadok alatt erősen beépült a magyar névállományba. Ennek köszönhetően jobban tudott függetlenedni a kultusztól, többen választották más okból. Ezt tükrözik azok a változások, amelyek a kultusztörténeti változásokkal ellentétes irányúak: e név sorsát ugyanis már egyéb társadalmi, kulturális és nyelvi tényezők is befolyásolták és befolyásolják, s tipikusan egyre erösebben, mint a szentkultusz. A Demeter ezzel szemben szorosabban kötődött a kultuszhoz, így tiszteletének erőteljes gyengülése a név ritkává válását is maga után vonta.

Az esettanulmány legfőbb tanulsága, hogy a felhasznált adatbázisok alapján - a számos egyéb lehetséges névadási indíték, illetve ezek feltárhatatlansága ellenére - valóban kimutathatók a szentkultuszok hatásai az egyénnévadásra. Ugyanakkor a jelenleg rendelkezésünkre álló adatbázisok közti időbeli lyukak, területi (országos vagy regionális) eltérések, a gyűjtést és a feldolgozást érintő módszertani különbségek megnehezítik, kevésbé pontossá teszik az eredmények értelmezését. Ezt csak egy egységes elvek alapján létrehozandó, időben, térben és társadalmi szempontból is minél átfogóbb egyénnévtörténeti adatbázissal lehetne kiküszöbölni, amelynek létrehozása azonban csakis egy több tudomány képviselőiből álló, jövőbeli kutatócsoport sokéves munkájával képzelhető el.

Kulcsszók: adatbázis, egyénnév, gyakoriság, szentkultusz, névadási szokások, névföldrajz.

\section{Hivatkozott irodalom}

ÁSznt. = FEHÉRTÓI KATALIN, Árpád-kori személynévtár 1000-1301. Akadémiai Kiadó, Budapest, 2004.

BÁLINT SÁNDOR 1977. Ünnepi kalendárium. A Mária-ünnepek és jelesebb napok hazai és közép-európai hagyományvilágából 1-2. Szent István Társulat, Budapest. 
BÁRTH DÁNIEL 2007. Szent Demeter és a magyarországi népi kultúra. In: TÓTH PÉTER szerk., Szent Demeter. Magyarország elfeledett védöszentje. Balassi Kiadó, Budapest. 206-214. FEHÉRTÓI KATALIN 1968. Egy XIV. századi nagybirtok jobbágyainak személynévanyaga. Magyar Nyelv 64: 317-331.

FEHÉRTÓI KATALIN 1983. Árpád-kori kis személynévtár. Akadémiai Kiadó, Budapest.

FEHÉRTÓI KATALIN 1997. Árpád-kori közszói eredetü személyneveinkről. Magyar Nyelvőr 121: 71-75.

N. FodOR JÁNOS 2010. Személynevek rendszere a kései ómagyar korban. A Felsö-Tiszavidék személyneveinek nyelvi elemzése (1401-1526). Magyar Névtani Értekezések 2. ELTE BTK Magyar Nyelvtudományi és Finnugor Intézet, Budapest.

GULYÁs ÉVA 1997. Szent György középkori kultusza és legendája a néphagyományban. Tisicum. A Jász-Nagykun-Szolnok Megyei Múzeumok Évkönyve 10: 187-205.

Hajdú MinÁly 2003. Általános és magyar névtan. Személynevek. Osiris Kiadó, Budapest.

HoFFMANN ISTVÁN 2015. A névtan és a társtudományok. In: FARKAS TAMÁs - SLÍZ MARIANN szerk., Magyar névkutatás a 21. század elején. Magyar Nyelvtudományi Társaság - ELTE Magyar Nyelvtudományi és Finnugor Intézet, Budapest. 11-22.

HofFMANN ISTVÁN 2016. A Szentmárton településnevek. Helynévtörténeti Tanulmányok 12: $81-100$.

KlanicZay GÁBOR 2018. Saints' Cults in Medieval Central Europe. Rivalries and Alliences. In: Petersen, Nils Holger - MÄnd, AnU - SAlvadó, SEBAstián SANDS, TRACEY R. eds., Symbolic Identity and the Cultural Memory of Saints. Cambridge Scholars Publishing, Newcastle upon Tyne. 21-41.

Magyar Zoltán 2006. Szent György a magyar kultúrtörténetben. A Kárpát-medence Szent György-hagyományainak néprajzi és müvelödéstörténeti rétege. Kairosz Kiadó, Budapest.

MEZÖ ANDRÁs 1970. A Várdai-birtokok jobbágynevei a XV. század közepén. A Kisvárdai Vármúzeum Kiadványai 3. A Kisvárdai Járási Tanács Végrehajtó Bizottsága, Kisvárda.

MEZŐ ANDRÁs 1996. A templomcím a magyar helységnevekben (11-15. század). METEMkönyvek 15. Magyar Egyháztörténeti Enciklopédia Munkaközösség, Budapest.

MKL. = Magyar katolikus lexikon 1-14. Főszerk. Diós ISTVÁN. Szent István Társulat, Budapest, 1993-2009.

Népnyilv. = Népesség-nyilvántartási statisztikák a Belügyminisztérium Nyilvántartások Vezetéséért Felelös Helyettes Államtitkárságának honlapján. https://www.nyilvantarto. hu/hu/statisztikak; Lakossági számadatok (2019. 08. 28.)

SLÍz MARIANN 2011. Anjou-kori személynévtár (1301-1342). Históriaantik, Budapest.

SLÍz MARIANN 2017a. Anjou-kori személynévtár (1343-1359). Magyar Nyelvtudományi Társaság, Budapest. https://doi.org/10.26546/5061158

SLÍz MARIANN 2017b. Between East and West. The influence of the cults of saints on personal name-giving in medieval Hungary. In: FeleCAN, OliviU ed., Name And Naming. Proceedings of the Fourth International Conference on Onomastics "Name and Naming”. Sacred and Profane in Onomastics. Baia Mare, September 5-7, 2017. Editura Mega - Editura Argonaut, Cluj-Napoca. 372-380.

SLÍZ MARIANN 2020. Cultural, social and political influences on the frequency of saints' names. In: Felecan, Oliviu - Bugheșiu, Alina eds., Proceedings of the Fifth In- 
ternational Conference on Onomastics „Name and Naming”. Multiculturalism in Onomastics. Editura Mega - Argonaut, Cluj-Napoca. Megjelenés előtt.

SLÍz MARIANN megj. e. Szent László kultuszának hatása a magyar személy- és helynévadásra. In: SLÍZ MARIANN szerk., Regum gemma, Ladislae. Tanulmányok Szent László királyról. Magyarságkutató Intézet Klasszika-filológiai Kutatóközpontja, Budapest. Megjelenés elött.

TERDIK SzILVESZTER 2007. Szent Demeter a müvészetben. In: TóTH P. szerk. 2007: 158205.

TMCsA. = Történeti magyar családnévatlasz 1715, 1720. Digitálisan tárolt adatbázis. Kutatásvezető: N. FODOR JÁNOS. http://www.csaladnevatlasz.hu

TótH PÉTER 2007a. A sirmiumi hagyomány eredete. In: TóTH P. szerk. 2007: 94-108.

TÓTH PÉTER 2007b. Szent Demeter hazai tiszteletének középkori és újkori emlékei. In: TÓTH P. szerk. 2007: 109-136.

TÓTH PÉTER szerk. 2007. Szent Demeter. Magyarország elfeledett védöszentje. Balassi Kiadó, Budapest.

TÓTH VALÉRIA 2012. Patrocíniumi településnevek Európában. Egy nemzetközi kutatási program eredményei. Magyar Nyelv 108: 292-303.

\section{The influence of the cults of Saint George and Saint Demetrius on Hungarian personal name giving}

The case study intends to demonstrate how the databases and name statistics of Hungarian historical anthroponymy built over the last decades can be useful in the study of cults of saints. The paper concentrates on given names, since the effect of saints' cults on personal name giving can mostly be detected by studying the historical changes, and the geographical and social diversity of the given name stock. The comparison of the two cults is motivated by several reasons. First, from a methodological viewpoint, it makes the evaluation of the measure of the impact more precise. Second, the two saints are linked by several aspects of cult history: both of them are Eastern soldier saints, frequently depicted together. However, their Hungarian cults developed differently: while Saint George became the prototype of soldier and knight saints in Hungary (and throughout Europe as well), the veneration of Saint Demetrius remained limited and was confined to the orthodox areas of the country since the early modern period. This difference can also be revealed in the popularity of the two names in Hungary. The name György 'George' has been far more frequent than Demeter 'Demetrius' from the beginning and is among the 100 most frequent given names of the whole population today, although its popularity has been decreasing. By contrast, Demeter can be counted as a definitely rare name. Their geographical distribution at the beginning of the 18 th century shows the same picture: while the name György was the second most frequent name in the whole population, Demeter was used in the regions habitated mostly by orthodox Romanians and Rusyns.

Keywords: database, given name, frequency, cults of saints, naming habits, name geography.

SLÍZ MARIANN

ELTE Eötvös Loránd Tudományegyetem 